\title{
Chemical composition and productivity for corn as affected by inorganic, organic nitrogen fertilizers and activators (Humic and Fulvic acid)
}

\author{
Mohammed A. Abd-Elzaher ${ }^{a *}$, Ibrahim Z. Ibrahim ${ }^{\mathrm{b}}$, Fathi A. Khalil ${ }^{\mathrm{a}}$ and Wagih S. Mohamed ${ }^{\mathrm{b}}$
}

${ }^{a}$ Soils, Water, and Environment Research Institute, Agricultural Research Center, Giza, Egypt

${ }^{b}$ Soil and water Department, Faculty of Agriculture, Minia University, Minia, Egypt

\begin{tabular}{l}
\hline C H R O N I C L E \\
\hline Article history: \\
Received July 20, 2021 \\
Received in revised form \\
October 20, 2021 \\
Accepted January 12, 2022 \\
Available online \\
January 12, 2022 \\
\hline Keywords: \\
Nitrogen fertilizer \\
Organic and Bio-fertilizer \\
Humic acid \\
Nutrients content \\
Corn \\
\hline
\end{tabular}
\begin{abstract}
A B S T R A C T
The present investigation was carried out to study the effects of inorganic, organic nitrogen fertilizers and activators (Humic and Fulvic acid) on chemical composition and productivity of corn. This study was conducted at Shandweel Agricultural Research Stations, Sohag Governorate, Egypt, and is situated at $26.6^{\circ} \mathrm{N}$ latitude and $37.7^{\circ} \mathrm{E}$ longitude. Its altitude is about $70 \mathrm{~m}$ above mean sea level. Also, this study was performed during two successive summer seasons 2014 and 2015. The experiments were laid down in split-split plot design with four replications. The treatments were included mineral nitrogen application in three levels (i.e. 60 , 90 and $120 \mathrm{~kg} \mathrm{~N}$ fed..$^{-1}$ ), organic and bio fertilizer application (without organic and bio fertilizer, $10 \mathrm{~m}^{3}$ FYM fed. ${ }^{-1}$ and Microbeine inoculume) as well as foliar spray of humic acid (water spraying, humic and fulvic acid spraying). The obtained results revealed that the interaction effects of all factors under study were significant for all studied traits.
\end{abstract}

C 2022 by the authors; licensee Growing Science, Canada.

\section{Introduction}

There are different applications for chemical compounds found recently, and this thing is important and can encourage scientists for more useful work. ${ }^{1-18}$ Corn (Zea mays L.) is one of the main cultivated cereals around the world. It is the third most important crop worldwide following wheat and rice. It is one of the important crops principally during the summer season in Egypt. Egypt produces about 5.8 million tons of white corn and 1.3 million tons of yellow corn annually. ${ }^{19}$ Intensive farming practices, which warrant high yield and quality, requiring extensive use of chemical fertilizers that are costly and create environmental problems. In fact, the danger of fixation and/or leaching of the synthetic fertilizers are harmful for soil and environment. ${ }^{20}$ Organic farming aims to produce healthy food and to respect the environment, emerging as an alternative to the negative consequences of conventional farming. In the context of sustainable organic agriculture, the successful use of biological nitrogen fixation without a decrease in productivity will reduce chemical fertilization. So, it is important to have previous knowledge of mineral nutrient requirements to optimize symbiotic nitrogen fixation and cereal crops production. The organic manure improves soil fertility by influencing its physical, chemical and biological properties. According to previous studies, ${ }^{21}$ the organic manure also improves the soil by the formation of clay humic complexes which increase the soil adsorbent capacity of basic nutrients (calcium, magnesium and potassium) and enhance the activity of microorganisms involved in the mineralization process. Bio-fertilizers may affect plant growth by one or more mechanisms such as nitrogen fixation, enhancing nutrient uptake, production of organic acids, protection against plant pathogens and excretion growth regulators like IAA and GA3, which stimulated growth and resulted in high yield. Bio-fertilizers are inputs containing microorganisms which are capable of mobilizing nutritive elements from non-usable form to usable form through biological processes, they include mainly the nitrogen fixing, phosphate solubilizing and plant growth promoting microorganisms. $^{22}$ Increasing and extending the role of bio-fertilizers can reduce the need for chemical fertilizers and decrease adverse environmental effects. Bio-fertilizers can also play a significant role in fixing atmospheric $\mathrm{N}$ and

* Corresponding author.

E-mail address: Maabdelzaher87@gmail.com (M. A. Abd-Elzaher)

(C) 2022 by the authors; licensee Growing Science, Canada

doi: $10.5267 /$ j.ccl.2022.1.001 
production of plant growth promoting substances. Therefore, in the development and implementation of sustainable agricultural techniques, bio-fertilization has a great importance in alleviating environmental pollution and deterioration of nature. ${ }^{23-25}$ Biological fertilizers have special significance in increasing crop production and preserving soil sustainable fertility. Inoculation with Bacillus megaterium increased significantly nutrients content and uptake (N, P and $\mathrm{K})$ in maize compared with control. ${ }^{26-28}$ Humic acid and Fulvic acid are of the major components of humus substances. ${ }^{29}$ The role of humic acid is well known in improving soil health and nutrient uptake by plants and mineral availability. ${ }^{30-32}$ The effect of humic acid foliar application was significant on all measured traits experiment of corn. Humic acid and fulvic acid increase the length and weight of root, number of lateral roots and flow of sap through the vessels. Moreover, they improve the quality and quantity of crops such as wheat, maize, etc., via increasing cell division and growth of crops, seeds germination. ${ }^{33}$ It is well known that maize crops need large amounts of fertilizers especially nitrogen. So, the major problems facing farmers are the high costs of excessive manufactured fertilizers needed for plants. Besides, these chemical fertilizers are considered as air, soil and water polluting agents during their production and utilization. Therefore, the present research aimed to study the effects of inorganic, organic nitrogen fertilizers and activators (Humic and Fulvic acid) on chemical composition and productivity of maize to reduce the mineral nitrogen fertilizer applications and also to reduce production costs.

\section{Results and Discussion}

\subsection{Grain yield ( $\left.\mathrm{kg} \mathrm{fed}^{-1}\right)$ and 100-grain weight (gm) of maize as affected by inorganic, organic nitrogen fertilizers and activators (H.A and F.A).}

A significant and gradual increase in grain yield (Table 1) was found by increasing nitrogen fertilizer levels from 60 to $120 \mathrm{~kg} \mathrm{~N}$ fed..$^{-1}$. The highest value of grain yield was obtained in applied $90 \mathrm{~kg} \mathrm{~N}$ fed.-.$^{-1}\left(3872.8 \mathrm{~kg}\right.$ fed..$\left.^{-1}\right)$. Nitrogen is the key element in increasing grain yield and quality of maize. Nitrogen contributes $1-4 \%$ of dry matter production of the plants. These results are in agreement with the reported data. ${ }^{34-35}$ Also, the results indicated that application of nitrogen fertilizer levels significantly increase the 100-grain weight (gm) of maize, over those obtained by control. The highest value of 100-grain weight (gm) was found by adding $90 \mathrm{~kg} \mathrm{~N}$ fed.- ${ }^{-1}(32.729 \mathrm{gm})$. The results are in good agreement with those obtained before. ${ }^{35}$

Data given in Table 1 indicated that a significant improvement in grain yield was found due to the application of FYM or bio-fertilizer (Microbeine) compared with the control. The highest grain yield was obtained in the application of $10 \mathrm{~m}^{3}$ FYM fed..$^{-1}\left(3706.3 \mathrm{~kg} \mathrm{fed} .^{-1}\right)$. The increase of growth and yield components may be due to the effect of applied nutrients and addition of FYM. This is in conformity with the findings reported before which demonstrate that an increase in maize grain yield after application of FYM may be due to slow release of nutrients to soil slowly for longer duration after decomposition resulting in better plant growth and yield attributing characters. ${ }^{36-37}$ Application of FYM or Microbeine significantly increase 100- grain weight more than the control. It was found that the highest value of 100- grain weight was obtained by adding Microbeine ( $32.480 \mathrm{gm})$, without significant difference could be noticed between. These findings is in the same side of those obtained before. ${ }^{38-41}$

Spraying of Humic acid or Fulvic acid (Table 1) gave significantly an increase in grain yield. The highest grain yield was obtained by spraying humic acid $\left(3675.5 \mathrm{~kg} \mathrm{fed}^{-1}\right)$. This may be attributed to humic acid functions on plant physiology, including enhancement of biomass yields, induction of lateral roots emergence, increase of cell respiration and membrane uptake of nutrients and exertion of hormone- like activities. ${ }^{42}$ Also, explained that humus had beneficial effects on nutrient uptake, transport and availability to maize plant that enhances the maize plant growth and increases maize yield. ${ }^{43}$ The ability of HA to release the nutrient slowly due to the decomposition of residue for a longer time could explain the improved in grain yield. ${ }^{44-45}$ Also, it was observed that H.A or F.A spraying had positive and significant effects on 100-grain weight on maize. The highest value of 100-grain weight (32.493 gm) was found by spraying humic acid. Similar results were obtained previously. ${ }^{31,46,47}$

By examining the data obtained in Table 1, it is clear that the interaction between nitrogen fertilizer levels and FYM or Microbeine led to a significant increase in grain yield. It was found that application of $90 \mathrm{~kg} \mathrm{~N}$ fed..$^{-1}$ combined with $10 \mathrm{~m}^{3}$ FYM fed. ${ }^{-1}$ gave the highest value of grain yield $\left(3999.2 \mathrm{~kg} \mathrm{fed} .^{-1}\right)$. Increasing grain yield due to application of nitrogen fertilizer levels combined with FYM over the control may be due to the effect of FYM in improving the physical and chemical properties of the soil. As well as organic manures plays a direct role in plant growth as a source of all necessary macro and micronutrients in available forms during mineralization. The results are consistent with the reported work before. $^{48-49}$ The results obtained also showed that the interaction effects between nitrogen fertilizer levels and FYM or Microbeine gave significant increases in the 100-grain weight more than those obtained by control. The highest value of 100 -grain weight (33.310 gm) was found by adding $90 \mathrm{~kg} \mathrm{~N}$ fed. ${ }^{-1}$ combined with $10 \mathrm{~m}^{3} \mathrm{FYM} \mathrm{fed}^{-1}$. These results are in agreement with those obtained before, ${ }^{41}$ which indicate that application of organic manure had distinctly influenced yield components of maize. This might be due to higher yield components that are directly responsible for grain yield that appeared to be determined by physiological characteristics, both during vegetative and reproductive phase of the crop growth. Moreover, it showed that the interaction between nitrogen fertilizers levels with the studied activators (H.A and 
F.A) gave significant and positive increases more than those without (H.A and F.A) in grain yield. The highest grain yield value $\left(3954.0 \mathrm{Kg} \mathrm{fed} .^{-1}\right)$ was found in adding $90 \mathrm{~kg} \mathrm{~N}$ fed. ${ }^{-1}$ with spraying of (H.A). Similar results were also reported, ${ }^{44}$ that indicate $20-23 \%$ of maize grain yield over control were obtained with application of humic acid in combination with recommended dose of NPK. These results are also in agreement with the reported work. ${ }^{50-51}$ Examining the data listed in Table 1, it is clear that the interaction between nitrogen fertilizer levels and the studied activators (H.A or F.A) had significant effects in increasing 100-grain weight, The highest value (32.949 gm) of 100-grain weight, was recorded in adding $90 \mathrm{~kg} \mathrm{~N}$ fed. $^{-1}$ with spraying (F.A). This finding is consistent with studies conducted before. ${ }^{43,52}$ Fulvic acid stimulates and balances cells, creating optimum growth and replication conditions. ${ }^{53}$

Also, the results indicated that the interaction effect between adding FYM or Microbeine with spraying of H.A or F.A give significant effect on grain yield. The highest value was obtained by adding $10 \mathrm{~m}^{3} \mathrm{FYM}$ fed. ${ }^{-1}$ with spraying of H.A $\left(3758.8 \mathrm{Kg} \mathrm{fed} .^{-1}\right)$. These results are in agreement with the findings reported before. ${ }^{54}$ The results in Table 1 shows that application of FYM or Microbeine combined with studied activators (H.A or F.A) had a significant effect on increasing 100-grain weight (gm). The highest value (32.984 gm) of 100-grain weight was obtained by applying Microbeine alone. These results to some extent corroborate the findings reported before. ${ }^{39,55,56}$

Consequently, Table 1 shows that interaction between the different factors under study led to significant increases in grain yield of maize. It was found that the highest grain yield $\left(4046.9 \mathrm{~kg} \mathrm{fed}^{-1}\right)$ was recorded in applied $90 \mathrm{~kg} \mathrm{~N}$ fed.-1 combined with $10 \mathrm{~m}^{3}$ FYM fed. ${ }^{-1}$ with spraying (F.A). These results were in harmony with the findings reported before. ${ }^{49,54}$ Moreover, show that interactions between all factors under study led to significant increases in 100-grain weight more than those obtained by control $\left(60 \mathrm{~kg} \mathrm{~N}\right.$ fed. $\left.{ }^{-1}\right)$. The highest of 100 -grain weight $(34.701 \mathrm{gm})$, was resulted in adding $90 \mathrm{~kg} \mathrm{~N}$ fed. ${ }^{-1}$ combined with $10 \mathrm{~m}^{3}$ FYM fed..$^{-1}$ and spraying (H.A). These results are in agreement with the data obtained before. ${ }^{57,58}$

Table 1. Grain yield $\left(\mathrm{kg} \mathrm{fed} .^{-1}\right)$ and 100-grain weight $(\mathrm{gm})$ of maize plants as affected by inorganic, organic nitrogen fertilizers and activators (H.A and F.A)

\begin{tabular}{|c|c|c|c|c|c|c|c|c|c|}
\hline \multicolumn{2}{|c|}{ Treatments } & \multicolumn{4}{|c|}{ Grain yield (kg fed..$\left.^{-1}\right)$} & \multicolumn{4}{|c|}{ 100-grain weight (gm) } \\
\hline \multirow{2}{*}{$\begin{array}{l}\text { Mineral } \\
\text { nitrogen } \\
\text { fertilizer } \\
\text { (A) }\end{array}$} & \multirow{2}{*}{$\begin{array}{c}\text { Organic } \\
\text { \& bio } \\
\text { fertilizer } \\
\text { (B) }\end{array}$} & \multicolumn{8}{|c|}{ Foliar application of Humic \& Fulvic acic (C) } \\
\hline & & $\begin{array}{l}\text { Water } \\
\text { spray }\end{array}$ & $\begin{array}{c}\text { Humic } \\
\text { spray }\end{array}$ & $\begin{array}{l}\text { Fulvic } \\
\text { spray }\end{array}$ & Average & $\begin{array}{l}\text { Water } \\
\text { spray }\end{array}$ & $\begin{array}{c}\text { Humic } \\
\text { spray }\end{array}$ & $\begin{array}{l}\text { Fulvic } \\
\text { spray }\end{array}$ & Average \\
\hline \multirow{3}{*}{$\begin{array}{c}60 \mathrm{~kg} \\
\mathrm{~N} \mathrm{Fed.}{ }^{-1} \\
\text { (Control) }\end{array}$} & (without) & 2931.3 & 3064.3 & 3071.1 & 3022.2 & 29.672 & 31.836 & 29.727 & 30.412 \\
\hline & Org. & 3084.7 & 3306.3 & 3229.8 & 3206.9 & 30.636 & 31.975 & 32.794 & 31.802 \\
\hline & Bio. & 3137.2 & 3222.5 & 3215.1 & 3191.6 & 32.126 & 31.985 & 32.080 & 32.064 \\
\hline \multicolumn{2}{|l|}{ Average } & 3051.1 & 3197.7 & 3172.0 & 3140.2 & 30.812 & 31.932 & 31.534 & 31.426 \\
\hline \multirow{3}{*}{$\begin{array}{c}90 \mathrm{~kg} \\
\text { N Fed. }^{-1}\end{array}$} & (without) & 3599.9 & 3894.5 & 3755.2 & 3749.8 & 31.636 & 31.604 & 32.655 & 31.965 \\
\hline & Org. & 3946.4 & 4004.4 & 4046.9 & 3999.2 & 32.076 & 34.701 & 33.151 & 33.310 \\
\hline & Bio. & 3822.5 & 3963.1 & 3822.9 & 3869.5 & 33.919 & 31.780 & 33.040 & 32.913 \\
\hline \multicolumn{2}{|l|}{ Average } & 3789.6 & 3954.0 & 3875.0 & 3872.8 & 32.544 & 32.695 & 32.949 & 32.729 \\
\hline \multirow{3}{*}{$\begin{array}{c}120 \mathrm{~kg} \\
\text { N Fed. }^{-1}\end{array}$} & (without) & 3784.7 & 3797.4 & 3809.3 & 3797.2 & 31.440 & 33.177 & 31.766 & 32.128 \\
\hline & Org. & 3869.7 & 3965.9 & 3902.4 & 3912.7 & 32.439 & 32.213 & 31.586 & 32.079 \\
\hline & Bio. & 3812.9 & 3861.7 & 3825.8 & 3833.5 & 32.908 & 33.163 & 31.324 & 32.465 \\
\hline \multicolumn{2}{|l|}{ Average } & 3822.4 & 3875.0 & 3845.9 & 3847.8 & 32.262 & 32.851 & 31.559 & 32.224 \\
\hline \multirow{3}{*}{$\begin{array}{l}\text { Average } \\
\text { for Org. \& } \\
\text { Bio. }\end{array}$} & (without) & 3438.6 & 3585.4 & 3545.2 & 3523.1 & 30.916 & 32.206 & 31.383 & 31.501 \\
\hline & Org. & 3633.6 & 3758.8 & 3726.4 & 3706.3 & 31.717 & 32.963 & 32.510 & 32.397 \\
\hline & Bio. & 3590.9 & 3682.4 & 3621.3 & 3631.5 & 32.984 & 32.309 & 32.148 & 32.480 \\
\hline \multicolumn{2}{|l|}{ Average } & 3554.4 & 3675.5 & 3630.9 & & 31.872 & 32.493 & 32.014 & \\
\hline \multicolumn{2}{|c|}{ L.S.D at } & & 0.05 & & & & 0.05 & & \\
\hline \multicolumn{2}{|c|}{ A } & & 18.2 & & & & 0.087 & & \\
\hline \multicolumn{2}{|c|}{$B$} & & 20.8 & & & & 0.195 & & \\
\hline \multicolumn{2}{|c|}{ C } & & 36.0 & & & & 0.339 & & \\
\hline \multicolumn{2}{|c|}{$A \times B$} & & 19.3 & & & & 0.203 & & \\
\hline \multicolumn{2}{|c|}{$A \times C$} & & 33.4 & & & & 0.351 & & \\
\hline \multicolumn{2}{|c|}{$B \times C$} & & 33.4 & & & & 0.351 & & \\
\hline \multicolumn{2}{|c|}{$A \times B \times C$} & & 57.8 & & & & 0.609 & & \\
\hline
\end{tabular}

2.2 Chemical composition of maize i.e. $N, P$ and $K$ content in leaves and grains $\left(\mathrm{g} \mathrm{kg}^{-1}\right)$ as affected by inorganic, organic nitrogen fertilizers and activators (H.A and F.A).

\subsubsection{Nitrogen content in leaves and grains $\left(\mathrm{g} \mathrm{kg}^{-1}\right)$ of maize.}

The data presented in Table 2 show that $\mathrm{N}$ content (\%) in leaves of maize increased by increasing nitrogen levels from 60 up to $120 \mathrm{~kg} \mathrm{~N}$ fed. ${ }^{-1}$. The addition of 90 and $120 \mathrm{~kg} \mathrm{~N}$ fed. ${ }^{-1}$, gave a significant increase in $\mathrm{N}$ content in leaves and these 
increases were increased by 4.34 and $7.09 \%$, respectively, more than those obtained by $60 \mathrm{Kg} \mathrm{N}$ fed. ${ }^{-1}$ (control). They indicated that increasing nitrogen levels led to an increase in nitrogen content in leaves. ${ }^{59}$ Results, showed that there is a significant and gradual increase in $\mathrm{N}$ content in grains by increasing nitrogen levels from 60 up to $120 \mathrm{~kg} \mathrm{~N}$ fed.-.$^{-1}$ Addition of 90 and $120 \mathrm{~kg} \mathrm{~N}$ fed..$^{-1}$, gave a significant increase in $\mathrm{N}$ content in grains. Their increased percentages were 7.79 and $18.34 \%$, respectively, from those obtained by $60 \mathrm{~kg} \mathrm{~N}$ fed..$^{-1}$ (control). They reported that varying levels of nitrogen influenced the concentration of nutrients $\mathrm{N}, \mathrm{P}$ and $\mathrm{K}$ in maize grain significantly. ${ }^{60-61}$ Application of FYM or Microbeine significantly increased $\mathrm{N}$ content in leaves more than those obtained by control (without organic and bio-fertilizers). Application of $10 \mathrm{~m}^{3}$ FYM fed..$^{-1}$ and Microbeine gave a significant increase in $\mathrm{N}$ content in leaves and these increases amounted by 4.14 and $4.14 \%$, respectively, more than those obtained by control. Consequently, It can be observed that the effect of added FYM or Microbeine on $\mathrm{N}$ content in grains in both seasons under study was significant. Application of $10 \mathrm{~m}^{3}$ FYM fed..$^{-1}$ and Microbeine resulted in a significant $\mathrm{N}$ content in grains and these increases amounted to 4.74 and $3.40 \%$ more than those obtained by control, respectively. The maximum value of $\mathrm{N}$ content in grains $\left(17.23 \mathrm{~g} \mathrm{~kg}^{-1}\right)$ was recorded by adding $10 \mathrm{~m}^{3} \mathrm{FYM} \mathrm{fed.}{ }^{-1}$. These results are in agreement with the reported work, ${ }^{62,63,64,41}$ which indicated that $\mathrm{N}$ content in grain and stover of maize was significantly influenced by application of FYM. In case of adding Microbeine, it was reported that $\mathrm{N}$ content in grain and stover of maize was significantly influenced by seed inoculation with biofertilizers. ${ }^{65,66}$

Spraying H.A and F.A activators resulted in significant increases in $\mathrm{N}$ content in leaves and grains. The highest of $\mathrm{N}$ content in leaves was found by spraying H.A $\left(32.19 \mathrm{~g} \mathrm{~kg}^{-1}\right)$. While, the highest value of $\mathrm{N}$ content in grains $\left(17.14 \mathrm{~g} \mathrm{~kg}^{-1}\right)$ was obtained with spraying of F.A. These results are in agreement with the work obtained before which indicated that the minerals (N, P and K) content of maize fodder significantly varied between HA levels. ${ }^{67,68}$ Higher mineral and total nitrogen in stem, leaves and grains at maturity in which $2.5 \mathrm{~kg} \mathrm{ha}^{-1}$ of humic acid was applied. Also, it was reported that humic substances provoked a better efficiency of plant water uptake and improved the mineral nutrition and grain protein content. ${ }^{69-70}$ Table 2 shows that interactions between nitrogen fertilizer levels and FYM or Microbeine led to significant and positive increases in $\mathrm{N}$ content in leaves and grains more than those obtained by control. Adding $120 \mathrm{~kg} \mathrm{~N}$ fed. ${ }^{-1}$ alone obtained the highest value of $\mathrm{N}$ content in leaves $\left(32.90 \mathrm{~g} \mathrm{~kg}^{-1}\right)$. Whereas, The highest of $\mathrm{N}$ content in grains $\left(19.25 \mathrm{~g} \mathrm{~kg}^{-1}\right)$ was resulted by adding $120 \mathrm{~kg} \mathrm{~N}$ fed. ${ }^{-1}$ combined with $10 \mathrm{~m}^{3}$ FYM fed..$^{-1}$. Similar results were found before, ${ }^{59,60,61}$ which indicated that increasing nitrogen levels led to an increase in nitrogen content in leaves. Also, it was reported that $\mathrm{N}$ content in grain and stover of maize was significantly influenced by application of FYM. ${ }^{62,63,64,41}$

Table 2. Nitrogen content in leaves and grains $\left(\mathrm{g} \mathrm{kg}^{-1}\right)$ of maize plants as affected by inorganic, organic nitrogen fertilizers and activators (H.A and F.A)

\begin{tabular}{|c|c|c|c|c|c|c|c|c|c|}
\hline \multicolumn{2}{|c|}{ Treatments } & \multicolumn{4}{|c|}{$\mathrm{N}$ content in leaves $\left(\mathrm{g} \mathrm{kg}^{-1}\right)$} & \multicolumn{4}{|c|}{$\mathrm{N}$ content in grains $\left(\mathrm{g} \mathrm{kg}^{-1}\right)$} \\
\hline \multirow{2}{*}{$\begin{array}{l}\text { Mineral } \\
\text { nitrogen } \\
\text { fertilizer } \\
\text { (A) }\end{array}$} & \multirow{2}{*}{$\begin{array}{l}\text { Organic } \\
\text { \& bio } \\
\text { fertilizer } \\
\text { (B) }\end{array}$} & \multicolumn{8}{|c|}{ Foliar application of Humic \& Fulvic acic (C) } \\
\hline & & $\begin{array}{l}\text { Water } \\
\text { spray }\end{array}$ & $\begin{array}{l}\text { Humic } \\
\text { spray }\end{array}$ & $\begin{array}{l}\text { Fulvic } \\
\text { spray }\end{array}$ & Average & $\begin{array}{l}\text { Water } \\
\text { spray }\end{array}$ & $\begin{array}{c}\text { Humic } \\
\text { spray }\end{array}$ & $\begin{array}{l}\text { Fulvic } \\
\text { spray }\end{array}$ & Average \\
\hline \multirow{3}{*}{$\begin{array}{c}60 \mathrm{~kg} \\
\mathrm{~N} \text { Fed. }{ }^{-1} \\
\text { (Control) }\end{array}$} & (without) & 27.74 & 30.46 & 29.08 & 29.10 & 14.48 & 15.23 & 15.38 & 15.03 \\
\hline & Org. & 30.83 & 31.35 & 31.62 & 31.27 & 15.23 & 15.79 & 16.12 & 15.71 \\
\hline & Bio. & 31.27 & 31.27 & 31.94 & 31.49 & 15.00 & 16.31 & 16.31 & 15.87 \\
\hline \multicolumn{2}{|l|}{ Average } & 29.95 & 31.03 & 30.88 & 30.62 & 14.90 & 15.78 & 15.94 & 15.54 \\
\hline \multirow{3}{*}{$\begin{array}{c}90 \mathrm{~kg} \\
\text { N Fed. }^{-1}\end{array}$} & (without) & 29.95 & 31.89 & 30.58 & 30.80 & 16.60 & 16.77 & 16.59 & 16.65 \\
\hline & Org. & 32.23 & 33.47 & 31.85 & 32.52 & 16.60 & 16.73 & 16.83 & 16.72 \\
\hline & Bio. & 32.27 & 32.80 & 32.49 & 32.52 & 16.63 & 16.91 & 17.13 & 16.89 \\
\hline \multicolumn{2}{|l|}{ Average } & 31.49 & 32.72 & 31.64 & 31.95 & 16.61 & 16.80 & 16.85 & 16.75 \\
\hline \multirow{3}{*}{$\begin{array}{c}120 \mathrm{~kg} \\
\mathrm{~N} \mathrm{Fed}^{-1}\end{array}$} & (without) & 35.35 & 32.89 & 30.45 & 32.90 & 17.58 & 17.53 & 17.85 & 17.66 \\
\hline & Org. & 33.42 & 33.32 & 31.83 & 32.86 & 18.08 & 20.25 & 19.41 & 19.25 \\
\hline & Bio. & 31.72 & 32.27 & 33.88 & 32.63 & 17.81 & 18.41 & 18.62 & 18.28 \\
\hline \multicolumn{2}{|l|}{ Average } & 33.50 & 32.83 & 32.05 & 32.79 & 17.83 & 18.73 & 18.63 & 18.39 \\
\hline \multirow{3}{*}{$\begin{array}{c}\text { Average } \\
\text { for Org. \& } \\
\text { Bio. }\end{array}$} & (without) & 31.01 & 31.75 & 30.03 & 30.93 & 16.22 & 16.51 & 16.61 & 16.45 \\
\hline & Org. & 32.16 & 32.71 & 31.77 & 32.21 & 16.64 & 17.59 & 17.45 & 17.23 \\
\hline & Bio. & 31.76 & 32.12 & 32.77 & 32.21 & 16.48 & 17.21 & 17.35 & 17.01 \\
\hline \multicolumn{2}{|l|}{ Average } & 31.64 & 32.19 & 31.52 & & 16.45 & 17.10 & 17.14 & \\
\hline \multicolumn{2}{|c|}{ L.S.D at } & & 0.05 & & & & 0.05 & & \\
\hline \multicolumn{2}{|c|}{$A$} & & 0.27 & & & & 0.16 & & \\
\hline \multicolumn{2}{|c|}{ B } & & 0.30 & & & & 0.12 & & \\
\hline \multicolumn{2}{|c|}{ C } & & 0.53 & & & & 0.20 & & \\
\hline \multicolumn{2}{|c|}{$A \times B$} & & 0.28 & & & & 0.12 & & \\
\hline \multicolumn{2}{|c|}{$A \times C$} & & 0.49 & & & & 0.21 & & \\
\hline \multicolumn{2}{|c|}{$B \times C$} & & 0.49 & & & & 0.21 & & \\
\hline \multicolumn{2}{|c|}{$A \times B \times C$} & & 0.84 & & & & 0.37 & & \\
\hline
\end{tabular}


By examining the data in Table 2, it is clear that the interaction between nitrogen fertilizer levels and spraying of H.A or F.A gave significant increase in $\mathrm{N}$ content in leaves and grains more than those obtained by spraying water only. The highest values of $\mathrm{N}$ content in leaves and grains were obtained by applying $120 \mathrm{~kg} \mathrm{~N}$ fed. ${ }^{-1}$ with spraying of H.A (32.83 and $\left.18.73 \mathrm{~g} \mathrm{~kg}^{-1}\right)$, respectively. Similar results were reported before ${ }^{59,60,61}$ which indicated that the nutrient concentration in grains enhanced significantly with the application of higher levels of $\mathrm{N}$ as compared with lower doses of $\mathrm{N}$. Also, the humic acid can obviously promote the absorption of nitrogen, phosphorus and potassium by maize plants with an obvious increase of the contents of nitrogen and potassium oxide in the stem and leaves of maize plants, $10 \%$ humic acid added in urea is better than other treatments in comprehensive effects. ${ }^{71}$

The data in Table 2 indicated that the interaction effects between FYM or Microbeine combined with spraying of H.A or F.A had positive and significant effects on increasing $\mathrm{N}$ content in leaves and grains. The highest value of $\mathrm{N}$ content was obtained by adding Microbeine combined with spraying F.A $\left(32.77 \mathrm{~g} \mathrm{~kg}^{-1}\right)$. However, The highest value of $\mathrm{N}$ content in grains $\left(17.59 \mathrm{~g} \mathrm{~kg}^{-1}\right)$ was obtained by adding $10 \mathrm{~m}^{3} \mathrm{FYM} \mathrm{fed} .^{-1}$ with spraying H.A. Similar results were reported before. $^{41,64,67,72}$

The interaction between all studied factors had a positive and significant $\mathrm{N}$ content in leaves and grains. The highest value of $\mathrm{N}$ content in leaves $\left(35.35 \mathrm{~g} \mathrm{~kg}^{-1}\right)$ was obtained by adding $120 \mathrm{~kg} \mathrm{~N}$ fed. $^{-1}$ alone. But, the highest of $\mathrm{N}$ content in grains $\left(20.25 \mathrm{~g} \mathrm{~kg}^{-1}\right)$ was produced by the treatment received $120 \mathrm{~kg} \mathrm{~N}$ fed. ${ }^{-1}$ beside $10 \mathrm{~m}^{3} \mathrm{FYM}$ fed. ${ }^{-1}$ with spraying H.A.

\subsubsection{Phosphorus content in leaves and grains $\left(\mathrm{g} \mathrm{kg}^{-1}\right)$ of maize.}

Data presented in Table 3 show that $\mathrm{P}$ content in leaves and grains $\left(\mathrm{g} \mathrm{kg}^{-1}\right)$ of maize increased by increasing nitrogen level up to $120 \mathrm{~kg} \mathrm{~N}$ fed..$^{-1}$. The addition of 90 and $120 \mathrm{~kg} \mathrm{~N}$ fed.-.$^{-1}$ gave a significant increase in $P$ content in leaves which in percentage were 4.09 and $8.49 \%$, respectively, more than those obtained by $60 \mathrm{~kg} \mathrm{~N}$ fed. ${ }^{-1}$ (control), respectively. The maximum value of phosphorus content $\left(3.45 \mathrm{~g} \mathrm{~kg}^{-1}\right)$ was recorded by adding $120 \mathrm{~kg} \mathrm{~N}$ fed.-.$^{-1}$ Addition of 90 and $120 \mathrm{~kg} \mathrm{~N}$ fed. $^{-1}$, gave significant increases in P content in grains; these increases were 4.11 and $7.97 \%$, from that obtained by $60 \mathrm{~kg}$ $\mathrm{N} \mathrm{fed} .^{-1}$ (control), respectively.

Table 3. Phosphorus content in leaves and grains $\left(\mathrm{g} \mathrm{kg}^{-1}\right)$ of maize plants as affected by inorganic, organic nitrogen fertilizers and activators (H.A and F.A)

\begin{tabular}{|c|c|c|c|c|c|c|c|c|c|}
\hline \multicolumn{2}{|c|}{ Treatments } & \multicolumn{4}{|c|}{$P$ content in leaves $\left(\mathrm{g} \mathrm{kg}^{-1}\right)$} & \multicolumn{4}{|c|}{$P$ content in grains $\left(\mathrm{g} \mathrm{kg}^{-1}\right)$} \\
\hline \multirow{2}{*}{$\begin{array}{l}\text { Mineral } \\
\text { nitrogen } \\
\text { fertilizer } \\
\text { (A) }\end{array}$} & \multirow{2}{*}{$\begin{array}{c}\text { Organic } \\
\text { \& bio } \\
\text { fertilizer } \\
\text { (B) }\end{array}$} & \multicolumn{8}{|c|}{ Foliar application of Humic \& Fulvic acid (C) } \\
\hline & & $\begin{array}{l}\text { Water } \\
\text { spray }\end{array}$ & $\begin{array}{c}\text { Humic } \\
\text { spray }\end{array}$ & $\begin{array}{l}\text { Fulvic } \\
\text { spray }\end{array}$ & Average & $\begin{array}{l}\text { Water } \\
\text { spray }\end{array}$ & $\begin{array}{c}\text { Humic } \\
\text { spray }\end{array}$ & $\begin{array}{l}\text { Fulvic } \\
\text { spray }\end{array}$ & Average \\
\hline \multirow{3}{*}{$\begin{array}{l}60 \mathrm{~kg} \\
\mathrm{~N} \mathrm{Fed.}^{-1} \\
\text { (Control) }\end{array}$} & (without) & 2.81 & 3.61 & 3.05 & 3.16 & 3.94 & 4.01 & 4.20 & 4.05 \\
\hline & Org. & 3.07 & 3.17 & 3.08 & 3.10 & 4.09 & 4.34 & 4.25 & 4.23 \\
\hline & Bio. & 3.25 & 3.18 & 3.43 & 3.29 & 3.97 & 4.22 & 4.21 & 4.13 \\
\hline \multicolumn{2}{|l|}{ Average } & 3.04 & 3.32 & 3.19 & 3.18 & 4.00 & 4.19 & 4.22 & 4.14 \\
\hline \multirow{3}{*}{$\begin{array}{c}90 \mathrm{~kg} \\
\text { N Fed. }^{-1}\end{array}$} & (without) & 3.07 & 3.14 & 3.33 & 3.18 & 4.03 & 4.35 & 4.33 & 4.23 \\
\hline & Org. & 3.54 & 3.51 & 3.34 & 3.46 & 4.32 & 4.31 & 4.30 & 4.31 \\
\hline & Bio. & 3.10 & 3.40 & 3.37 & 3.29 & 4.27 & 4.49 & 4.38 & 4.38 \\
\hline \multicolumn{2}{|l|}{ Average } & 3.24 & 3.35 & 3.34 & 3.31 & 4.20 & 4.38 & 4.34 & 4.31 \\
\hline \multirow{3}{*}{$\begin{array}{l}120 \mathrm{~kg} \\
\text { N Fed. }^{-1}\end{array}$} & (without) & 3.47 & 3.31 & 3.14 & 3.31 & 4.37 & 4.47 & 4.42 & 4.42 \\
\hline & Org. & 3.43 & 3.64 & 3.56 & 3.54 & 4.57 & 4.47 & 4.35 & 4.46 \\
\hline & Bio. & 3.43 & 3.57 & 3.49 & 3.50 & 4.57 & 4.57 & 4.48 & 4.54 \\
\hline \multicolumn{2}{|l|}{ Average } & 3.44 & 3.51 & 3.39 & 3.45 & 4.51 & 4.50 & 4.41 & 4.47 \\
\hline \multirow{3}{*}{$\begin{array}{c}\text { Average } \\
\text { for Org. \& } \\
\text { Bio. }\end{array}$} & (without) & 3.12 & 3.35 & 3.17 & 3.21 & 4.11 & 4.27 & 4.32 & 4.23 \\
\hline & Org. & 3.35 & 3.44 & 3.32 & 3.37 & 4.33 & 4.37 & 4.30 & 4.33 \\
\hline & Bio. & 3.26 & 3.38 & 3.43 & 3.36 & 4.27 & 4.43 & 4.35 & 4.35 \\
\hline \multicolumn{2}{|l|}{ Average } & 3.24 & 3.39 & 3.31 & & 4.24 & 4.36 & 4.32 & \\
\hline \multicolumn{2}{|l|}{ L.S.D at } & & 0.05 & & & & 0.05 & & \\
\hline \multicolumn{2}{|l|}{$A$} & & 0.03 & & & & 0.01 & & \\
\hline \multicolumn{2}{|l|}{ B } & & 0.02 & & & & 0.01 & & \\
\hline \multicolumn{2}{|l|}{ C } & & 0.04 & & & & 0.02 & & \\
\hline \multicolumn{2}{|c|}{$A \times B$} & & 0.02 & & & & 0.02 & & \\
\hline \multicolumn{2}{|c|}{$A \times C$} & & 0.04 & & & & 0.03 & & \\
\hline \multicolumn{2}{|c|}{$B \times C$} & & 0.04 & & & & 0.03 & & \\
\hline \multicolumn{2}{|c|}{$A \times B \times C$} & & 0.06 & & & & 0.05 & & \\
\hline
\end{tabular}


Data given in Table 3 clearly showed that application of FYM or Microbeine significantly increased P content in leaves and grains over those obtained with control (without organic and bio fertilizers). Application of $10 \mathrm{~m}^{3} \mathrm{FYM}_{\mathrm{Med}} \mathrm{-}^{-1}$ and Microbeine gave a significant increase in P content in leaves, which amounted by 4.98 and $4.67 \%$ more than the control, respectively. It can be observed that the application of $10 \mathrm{~m}^{3} \mathrm{FYM}$ fed..$^{-1}$ and Microbeine gave significant increases which amounted by 2.36 and $2.84 \%$ in $\mathrm{P}$ content in grains from that gained by control, respectively.

The results in Table 3, show that spraying H.A and F.A activators resulted in a significant increase in $\mathrm{P}$ content in leaves and grains. The highest value of phosphorus content in leaves was found by spraying of H.A ( $\left.3.39 \mathrm{~g} \mathrm{~kg}^{-1}\right)$, The highest of P content in grains $\left(4.36 \mathrm{~g} \mathrm{~kg}^{-1}\right)$ was obtained by spraying of H.A.

Table 3 showed that interactions between nitrogen fertilizer levels and FYM or Microbeine led to significant and positive increases in $\mathrm{P}$ content in leaves and grains more than those obtained by control. Adding $120 \mathrm{~kg} \mathrm{~N}$ fed.-.$^{-1}$ combined with 10 $\mathrm{m}^{3}$ FYM fed..$^{-1}$ obtained the highest value of $\mathrm{P}$ content $\left(3.54 \mathrm{~g} \mathrm{~kg}^{-1}\right)$. While, the highest value of $\mathrm{P}$ content in grains (4.54 $\mathrm{g} \mathrm{kg}^{-1}$ ) was resulted by adding $120 \mathrm{~kg} \mathrm{~N}$ fed. $^{-1}$ combined with Microbeine.

By examining the data in Table 3, it is clear that the interaction between nitrogen fertilizer levels and spraying of H.A or F.A gave significant increase in $\mathrm{P}$ content in leaves and grains. The highest phosphorus content in leaves was obtained by applying $120 \mathrm{~kg} \mathrm{~N}$ fed. ${ }^{-1}$ with spraying of H.A $\left(3.51 \mathrm{~g} \mathrm{~kg}^{-1}\right)$. Whereas, the highest value of phosphorus content in grains was obtained by applying $120 \mathrm{~kg} \mathrm{~N}$ fed. ${ }^{-1}$ alone $\left(4.51 \mathrm{~g} \mathrm{~kg}^{-1}\right)$.

The data in Table 3, indicated that the interaction effects between adding FYM or Microbeine with spraying H.A or F.A were significant on increasing $\mathrm{P}$ content in leaves and grains. The highest value of $\mathrm{P}$ content was obtained by adding $10 \mathrm{~m}^{3}$ FYM fed. ${ }^{-1}$ with spraying H.A $\left(3.44 \mathrm{~g} \mathrm{~kg}^{-1}\right)$. The highest value of P content in grains $\left(4.43 \mathrm{~g} \mathrm{~kg}^{-1}\right)$ was obtained by adding Microbeine with spraying H.A.

All interaction between the studied factors were significant in their effect on $\mathrm{P}$ content in leaves and grains of maize, Table 3. The highest value of $\mathrm{P}$ content in leaves $\left(3.64 \mathrm{~g} \mathrm{~kg}^{-1}\right)$ was obtained from the treatment received $120 \mathrm{~kg} \mathrm{~N}$ fed.combined with $10 \mathrm{~m}^{3}$ FYM fed. ${ }^{-1}$ with spraying H.A.

\subsubsection{Potassium content in leaves and grains $\left(\mathrm{g} \mathrm{kg}^{-1}\right)$ of maize.}

Results in Table 4 clearly showed that there is a significant and gradual increase in K content in leaves and grains by increasing nitrogen levels from 60 up to $120 \mathrm{~kg} \mathrm{~N}$ fed. ${ }^{-1}$. Values of $\mathrm{K}$ content in leaves were $30.90,31.90$ and $32.48 \mathrm{~g} \mathrm{~kg}^{-1}$ when 60,90 and $120 \mathrm{~kg} \mathrm{~N}$ fed. ${ }^{-1}$ were applied, respectively. Values of $\mathrm{K}$ content in grains by applying 60,90 and $120 \mathrm{~kg}$ $\mathrm{N}$ fed. ${ }^{-1}$ were 5.03, 5.22 and $5.30 \mathrm{~g} \mathrm{~kg}^{-1}$, respectively. Concerning the effect of FYM or Microbeine on K content in leaves of maize, data in Table 4, revealed that adding FYM or Microbeine had a significant effect on K content in leaves more than those obtained by control (without organic and bio fertilizers). The highest value of $\mathrm{K}$ content in leaves $\left(32.10 \mathrm{~g} \mathrm{~kg}^{-1}\right)$ was obtained by adding Microbeine. On the other hand, the effect of FYM or Microbeine on K content in grains, data in Table 4, revealed that the effect resulted in a significant decrease in $\mathrm{K}$ content in grains.

The data listed in Table 4 indicated that spraying the studied activators (H.A and F.A) gave significant increases in K content in leaves, The highest value of $\mathrm{K}$ content in leaves was found by spraying of F.A (31.93 $\left.\mathrm{g} \mathrm{kg}^{-1}\right)$. The data listed in Table 4 indicated that the differences in $\mathrm{K}$ content in grains by spraying each H.A and F.A were so narrow, without any significant differences. Whereas the effect of spraying each H.A and F.A resulted in a significant decline in K content in grains.

The interaction between nitrogen fertilizer levels and FYM or Microbeine gave a significant increase in $\mathrm{K}$ content in leaves and grains. The highest value was obtained by applying $120 \mathrm{~kg} \mathrm{~N}$ fed..$^{-1}$ combined with $10 \mathrm{~m}^{3} \mathrm{FYM} \mathrm{fed.}^{-1}(32.54 \mathrm{~g}$ $\mathrm{kg}^{-1}$ ) without difference between applying of $10 \mathrm{~m}^{3} \mathrm{FYM} \mathrm{fed.-1}$ and/or Microbeine. However, The highest value of $\mathrm{K}$ content in grains was obtained by applying $120 \mathrm{~kg} \mathrm{~N}$ fed.- ${ }^{-1}$ alone $\left(5.36 \mathrm{~g} \mathrm{~kg}^{-1}\right)$. These results are in agreement with those obtained before since it was reported that the nutrient concentration in both grain and stover enhanced significantly with the application of higher levels of $\mathrm{N}$ as compared with lower doses of $\mathrm{N}$. For the effect of microorganisms and microbial communities like Azotobacter sp. and Azospirillum sp. in the rhizosphere promotes the growth of the plant through the cycling and availability of nutrients, increasing the health of roots during the growth stage by competing with root pathogens and increasing the absorption of nutrients and water and also, it was noted that microbial enzymatic processes, organic substance could be mineralized and turn into inorganic substances to provide $\mathrm{N}, \mathrm{P}, \mathrm{K}$ and other nutrient that can be absorbed by maize. ${ }^{73,74,75}$ From the data in Table 4, the interaction between nitrogen fertilizer levels and spraying of H.A or F.A resulted in a significant increase in $\mathrm{K}$ content in leaves and grains. The highest value was obtained by applying $120 \mathrm{~kg} \mathrm{~N}$ fed. $^{-1}$ with spraying of H.A $\left(32.87 \mathrm{~g} \mathrm{~kg}^{-1}\right)$. While the highest value of $\mathrm{K}$ content in grains was obtained by applying $120 \mathrm{~kg}$ $\mathrm{N}$ fed. ${ }^{-1}$ alone $\left(5.40 \mathrm{~g} \mathrm{~kg}^{-1}\right)$. 
Table 4. Potassium content in leaves and grains $\left(\mathrm{g} \mathrm{kg}^{-1}\right)$ of maize plants as affected by inorganic, organic nitrogen fertilizers and activators (H.A and F.A)

\begin{tabular}{|c|c|c|c|c|c|c|c|c|c|}
\hline \multicolumn{2}{|c|}{ Treatments } & \multicolumn{4}{|c|}{ K content in leaves $\left(\mathrm{g} \mathrm{kg}^{-1}\right)$} & \multicolumn{4}{|c|}{ K content in grains $\left(\mathrm{g} \mathrm{kg}^{-1}\right)$} \\
\hline \multirow{2}{*}{$\begin{array}{l}\text { Mineral } \\
\text { nitrogen } \\
\text { fertilizer } \\
\text { (A) }\end{array}$} & \multirow{2}{*}{$\begin{array}{c}\text { Organic } \\
\text { \& Bio } \\
\text { fertilizer } \\
\text { (B) }\end{array}$} & \multicolumn{8}{|c|}{ Foliar application of Humic \& Fulvic acid (C) } \\
\hline & & $\begin{array}{l}\text { Water } \\
\text { spray }\end{array}$ & $\begin{array}{c}\text { Humic } \\
\text { spray }\end{array}$ & $\begin{array}{l}\text { Fulvic } \\
\text { spray }\end{array}$ & Average & $\begin{array}{l}\text { Water } \\
\text { spray }\end{array}$ & $\begin{array}{c}\text { Humic } \\
\text { spray }\end{array}$ & $\begin{array}{l}\text { Fulvic } \\
\text { spray }\end{array}$ & Average \\
\hline \multirow{3}{*}{$\begin{array}{c}60 \mathrm{~kg} \\
\text { N Fed. }{ }^{-1} \\
\text { (Control) }\end{array}$} & (without) & 28.74 & 31.05 & 30.64 & 30.14 & 5.12 & 5.06 & 4.99 & 5.06 \\
\hline & Org. & 31.56 & 31.52 & 31.09 & 31.39 & 5.02 & 4.85 & 5.17 & 5.01 \\
\hline & Bio. & 31.52 & 31.37 & 31.37 & 31.42 & 4.93 & 5.08 & 5.05 & 5.02 \\
\hline \multicolumn{2}{|l|}{ Average } & 30.61 & 31.31 & 31.03 & 30.98 & 5.02 & 4.99 & 5.07 & 5.03 \\
\hline \multirow{3}{*}{$\begin{array}{c}90 \mathrm{~kg} \\
\text { N Fed. }^{-1}\end{array}$} & (without) & 31.27 & 31.23 & 31.39 & 31.30 & 5.32 & 5.18 & 5.45 & 5.31 \\
\hline & Org. & 32.17 & 31.33 & 32.60 & 32.03 & 5.34 & 5.09 & 5.19 & 5.20 \\
\hline & Bio. & 33.01 & 31.75 & 32.36 & 32.37 & 5.10 & 5.23 & 5.10 & 5.14 \\
\hline \multicolumn{2}{|l|}{ Average } & 32.15 & 31.43 & 32.12 & 31.90 & 5.25 & 5.16 & 5.25 & 5.22 \\
\hline \multirow{3}{*}{$\begin{array}{l}120 \mathrm{~kg} \\
\text { N Fed. }^{-1}\end{array}$} & (without) & 31.88 & 32.68 & 32.59 & 32.38 & 5.50 & 5.39 & 5.21 & 5.36 \\
\hline & Org. & 32.44 & 32.59 & 32.60 & 32.54 & 5.28 & 5.22 & 5.20 & 5.23 \\
\hline & Bio. & 31.46 & 33.36 & 32.74 & 32.52 & 5.42 & 5.28 & 5.18 & 5.29 \\
\hline \multicolumn{2}{|l|}{ Average } & 31.92 & 32.87 & 32.64 & 32.48 & 5.40 & 5.29 & 5.19 & 5.30 \\
\hline \multirow{3}{*}{$\begin{array}{l}\text { Average } \\
\text { for Org. \& } \\
\text { Bio. }\end{array}$} & (without) & 30.63 & 31.65 & 31.54 & 31.27 & 5.31 & 5.21 & 5.21 & 5.24 \\
\hline & Org. & 32.05 & 31.81 & 32.10 & 31.99 & 5.21 & 5.05 & 5.19 & 5.15 \\
\hline & Bio. & 32.00 & 32.16 & 32.16 & 32.10 & 5.15 & 5.19 & 5.11 & 5.15 \\
\hline \multicolumn{2}{|l|}{ Average } & 31.56 & 31.87 & 31.93 & & 5.22 & 5.15 & 5.17 & \\
\hline \multicolumn{2}{|l|}{ L.S.D at } & & 0.05 & & & & 0.05 & & \\
\hline \multicolumn{2}{|l|}{$A$} & & 0.45 & & & & 0.03 & & \\
\hline \multicolumn{2}{|l|}{$B$} & & 0.20 & & & & 0.03 & & \\
\hline \multicolumn{2}{|l|}{$C$} & & 0.34 & & & & 0.05 & & \\
\hline \multicolumn{2}{|c|}{$A \times B$} & & 0.21 & & & & 0.03 & & \\
\hline \multicolumn{2}{|c|}{$A \times C$} & & 0.37 & & & & 0.05 & & \\
\hline \multicolumn{2}{|c|}{$B \times C$} & & 0.37 & & & & 0.05 & & \\
\hline \multicolumn{2}{|c|}{$A \times B \times C$} & & 0.64 & & & & 0.09 & & \\
\hline
\end{tabular}

Results in Table 4 have indicated that the interaction effects between adding FYM or Microbeine with spraying of H.A or F.A was significant on increasing K content in leaves. The highest value of K content in leaves $\left(32.16 \mathrm{~g} \mathrm{~kg}^{-1}\right) \mathrm{was} \mathrm{obtained}^{-1}$ by adding Microbeine with spraying of H.A, However, the same value of K content in leaves $\left(32.16 \mathrm{~g} \mathrm{~kg}^{-1}\right)$ was obtained by adding Microbeine with spraying F.A. On the other hand, it can be observed that the interaction effects between adding FYM or Microbeine with spraying of (H.A or F.A) was significant decrease on K content in grains. The interactions between all studied factors significantly affected potassium content in leaves and grains positively. The highest value of $\mathrm{K}$ content in leaves were $33.36 \mathrm{~g} \mathrm{~kg}^{-1}$ as a result from the treatment received $120 \mathrm{~kg} \mathrm{~N}$ fed.-1 combined with adding Microbeine under spraying H.A. However, the maximum value of $\mathrm{K}$ content in grains $\left(5.50 \mathrm{~g} \mathrm{~kg}^{-1}\right)$ was obtained by applying $120 \mathrm{~kg} \mathrm{~N}^{\mathrm{fed}}{ }^{-1}$ alone.

\section{Conclusion}

The obtained results revealed that a significant and gradual increase in grain yield ( $\mathrm{kg} \mathrm{fed}^{-1}, 100$-grain weight (gm) $\mathrm{N}$, $\mathrm{P}$ and $\mathrm{K}$ content in leaves and grains, were found by adding nitrogen fertilizer levels from 60 to $120 \mathrm{~kg} \mathrm{~N}^{-1} \mathrm{~d}^{-1}$. The results also revealed a significant improvement in grain yield $\left(\mathrm{kg} \mathrm{fed}^{-1}, 100\right.$-grain weight $(\mathrm{gm}) \mathrm{N}, \mathrm{P}$ and $\mathrm{K}$ content in leaves and grains due to the application of FYM or Microbein as compared with the control (without organic or bio- fertilizers). Applications of humic acid had a significant effect on all studied traits. The interaction effects of all factors under study were highly significant for all studied traits. Highest values in grain yield $\left(4046.9 \mathrm{~kg} \mathrm{fed}^{-1}\right)$ were obtained by adding $90 \mathrm{~kg}$ $\mathrm{N}$ fed ${ }^{-1}$. combined with $10 \mathrm{~m}^{3} \mathrm{FYM}$ fed ${ }^{-1}$. under spraying (F.A). The applications of $10 \mathrm{~m}^{3} \mathrm{FYM} \mathrm{fed}^{-1}$. or Microbein with spraying of H.A or F.A combined with $75 \%$ of the recommended dose of $\mathrm{N}$ fertilizer could be enough for improving soil fertility and produce grain yield equal or more than those obtained by the recommended dose.

\section{Experimental}

\subsection{Materials and methods}

Field experiments were conducted at Shandweel Agricultural Research Stations, Sohag Governorate, during two successive summer seasons (2014 and 2015) to study the effects of inorganic, organic nitrogen fertilizers and activators (Humic and Fulvic acid) on chemical composition and productivity of maize. The experimental design was a split-split plot with four replicates. Nitrogen levels were assigned to the main plots, application of farm yard manure (FYM) and biofertilizer to the sub-plots while spraying treatments were arranged as sub-sub-plots (Humic acid (H.A), Fulvic acid (F.A) and water spraying). 


\subsubsection{The treatments were as follows:}

A- Main plots: Nitrogen fertilizer levels.

a1- $60 \mathrm{Kg} \mathrm{N}$ fed. ${ }^{-1}$ (Control), a2- $90 \mathrm{Kg} \mathrm{N}$ fed. ${ }^{-1}$ and a3- $120 \mathrm{Kg} \mathrm{N}$ fed..$^{-1}$.

B-Sub-plots: organic and bio-fertilizers.

b1- Without organic or bio-fertilizers, b2- $10 \mathrm{~m}^{3}$ FYM fed.- ${ }^{-1}$ and b3- bio-fertilizer (Microbeine).

C-Sub-sub-plots: Foliar spraying of Humic or Fulvic acid.

c1- Water spraying, c2- Humic acid spraying and c3- Fulvic acid spraying.

Nitrogen fertilizer was applied in the form of urea $(46.5 \% \mathrm{~N})$. This fertilizer was applied in two equal portions, the first portion was added before the first irrigation and the other one was before the second irrigation. Potassium fertilizer in the form of potassium sulphate $\left(48 \% \mathrm{~K}_{2} \mathrm{O}\right)$ was added to all plots of the experiment at a rate of $24 \mathrm{~kg} \mathrm{~K} \mathrm{~K}_{2} \mathrm{O}$ fed.- ${ }^{-1}$ at planting. Super-phosphate $\left(15 \% \mathrm{P}_{2} \mathrm{O}_{5}\right)$ was added at the rate of $15 \mathrm{~kg} \mathrm{P}_{2} \mathrm{O}_{5}$ fed.- during land preparation. Farm yard manure (FYM) was added at the rate of $10 \mathrm{~m}^{3} \mathrm{FYM} \mathrm{fed} .^{-1}$ during land preparation. Bio-fertilizer (Microbeine), a mixture of phosphorus dissolving and $\mathrm{N}_{2}$-fixing bacteria, was produced and distributed commercially by General organization for Agriculture Equalization Fund (GOAEF), Ministry of Agriculture Egypt, Biofertilizer (Microbeine) was added as a soil application before the first irrigation. Foliar application of Humic and Fulvic acids (H.A and F.A) at a rate (4 liter/200 liter water per fed.). Two spraying times at 30 and 45 days after planting were done for H.A, F.A and water. Humic and Fulvic acid is a commercial product supplied from Bio Tec for Bio-cids and Fertilizers Company, Al Sadat City, Egypt.

Table 5. Some physical and chemical properties of the experimental soils

\begin{tabular}{|c|c|c|c|c|c|c|c|c|c|c|}
\hline \multicolumn{5}{|c|}{ Physical properties } & \multicolumn{6}{|c|}{ Chemical properties } \\
\hline \multicolumn{3}{|c|}{$\begin{array}{c}\text { Particle size distribution } \\
(\%)\end{array}$} & \multirow{2}{*}{\multicolumn{2}{|c|}{ Texture class }} & \multirow{2}{*}{$\begin{array}{l}\text { O.M } \\
\text { g kg-1 }^{-1}\end{array}$} & \multirow{2}{*}{\multicolumn{2}{|c|}{$\begin{array}{c}\mathrm{pH} \\
(1: 2.5) \\
\text { soil water susp. }\end{array}$}} & \multirow{2}{*}{\multicolumn{2}{|c|}{$\begin{array}{l}\mathrm{EC} \mathrm{dSm}^{-1}(1: 2.5) \\
\text { soil water ext. }\end{array}$}} & \multirow{2}{*}{$\begin{array}{l}\mathrm{CaCo}_{3} \\
\mathrm{~g} \mathrm{~kg}^{-1}\end{array}$} \\
\hline Sand & Silt & Clay & & & & & & & & \\
\hline 23.20 & 38.85 & 37.95 & $\mathrm{Cla}$ & $\mathrm{am}$ & 12.70 & & 56 & 1.11 & & 17.75 \\
\hline \multicolumn{8}{|c|}{ Soluble cations and anions } & \multicolumn{3}{|c|}{ Available macronutrients } \\
\hline \multicolumn{5}{|c|}{ Cations meq $\mathrm{L}^{-1}$} & \multicolumn{3}{|c|}{ Anions meq $\mathrm{L}^{-1}$} & \multirow{2}{*}{$\begin{array}{c}\mathrm{N} \\
\mathrm{mg} \mathrm{kg}^{-1}\end{array}$} & \multirow{2}{*}{$\begin{array}{c}\mathrm{P} \\
\mathrm{mg} \mathrm{kg}^{-1}\end{array}$} & \multirow{2}{*}{$\begin{array}{c}\mathrm{K} \\
\mathrm{mg} \mathrm{kg}^{-1}\end{array}$} \\
\hline $\mathrm{Ca}^{++}$ & $\mathrm{Mg}^{++}$ & $\mathrm{Na}^{+}$ & $\mathrm{K}^{+}$ & $\mathrm{CO}_{3}^{--}$ & $\mathrm{HCO}_{3}{ }^{-}$ & $\mathrm{Cl}^{-}$ & $\mathrm{SO}_{4}^{--}$ & & & \\
\hline 55.30 & 27.75 & 26.5 & 2.35 & 0.00 & 37.30 & 22.60 & 51.55 & 17.95 & 9.75 & 174.00 \\
\hline
\end{tabular}

Table 6. Physiochemical properties of the investigated farm yard manure (FYM)

\begin{tabular}{ccccccccccc}
\hline properties & $\mathrm{pH}$ & $\begin{array}{c}\mathrm{E} . \mathrm{C} \\
\mathrm{dSm}^{-1}\end{array}$ & $\begin{array}{c}\mathrm{N} \\
\mathrm{g} \mathrm{kg}^{-1}\end{array}$ & $\begin{array}{c}\mathrm{P} \\
\mathrm{g} \mathrm{kg}^{-1}\end{array}$ & $\begin{array}{c}\mathrm{K} \\
\mathrm{g} \mathrm{kg}^{-1}\end{array}$ & $\begin{array}{c}\mathrm{O} . \mathrm{M} \\
\mathrm{g} \mathrm{kg}^{-1}\end{array}$ & $\begin{array}{c}\mathrm{O} . \mathrm{C} \\
\mathrm{g} \mathrm{kg}^{-1}\end{array}$ & $\begin{array}{c}\mathrm{C} / \mathrm{N} \\
\text { ratio }\end{array}$ & $\begin{array}{c}\text { Bulk } \\
\text { density } \\
\left(\mathrm{kg} / \mathrm{m}^{3}\right)\end{array}$ & $\begin{array}{c}\text { Moisture } \\
\text { content } \\
(\%)\end{array}$ \\
\hline Value & 7.35 & 6.19 & 7.80 & 3.90 & 29.50 & 258.7 & 134.4 & 17.23 & 644 & 10.60 \\
\hline
\end{tabular}

\subsection{Measurement of soil properties}

Soil samples were taken before planting from the experimental sites in both seasons. Soil samples were taken from 0-30 $\mathrm{cm}$ depths, air-dried, crushed and sieved to pass through a $2 \mathrm{~mm}$ sieve, to determinate physical and chemical properties. Soil characterization for the experimental sites are listed in Table 5 and were determined a according to the following methods: Particle-size distribution was determined using the pipette method. ${ }^{76}$ Organic carbon was determined by the modified Walkely and Black method. ${ }^{77}$ Total calcium carbonate $\left(\mathrm{CaCO}_{3}\right)$ was determined using Collin's Calcimeter. ${ }^{76}$ Soil $\mathrm{pH}$ was measured in 1:2.5 soil: water suspension. ${ }^{77} \mathrm{EC}\left(\mathrm{dSm}^{-1}\right)$ was determined in 1:2.5 soil: water extract. ${ }^{77}$ Soluble cations and anions were determined in soil saturation extract using the standard methods. ${ }^{77}$ Available nitrogen was determined in the soil samples using micro-Kjeldahl method. ${ }^{78}$ Available phosphorus was extracted by $0.5 \mathrm{M} \mathrm{NaHCO}_{3}{ }^{79}$ and determined by the stannous chloride phosphomolybdic acid method. ${ }^{77}$ Available potassium was determined Flame Photometerically in 1 $\mathrm{N}$ ammonium acetate extract according to. ${ }^{77}$

\subsection{Measurement of farm yard manure (FYM) properties.}

Physiochemical properties of the investigated farm yard manure (FYM) are listed in Table 6 and were determined according to the following methods: $\mathrm{pH}$ was determined in 1:5 FYM: water suspension. $\mathrm{EC}\left(\mathrm{dSm}^{-1}\right)$ was determined in 1:5 FYM: water extract. ${ }^{77}$ Organic matter (O.M) was determined by weight loss on ignition at $430{ }^{\circ} \mathrm{C}$ for $24 \mathrm{~h}$ and total organic carbon (TOC) was calculated from (OM) according to the equation of Navarro. ${ }^{80}$ Bulk density was determined using the core method according to the method of Black. ${ }^{81}$ Total nitrogen was determined by using Kjeldahl digestion method. ${ }^{77}$ Total phosphorus was determined in FYM spectrophotometrically in the acid solution of the digested samples using ammonium molybdate and stannous chloride reagents. ${ }^{78}$ Total potassium was determined in the acid solution of the digested samples using flame photometric method according to Page. ${ }^{78}$ 


\subsection{Measurement growth parameters}

Plant growth, two plant samples were taken from each experimental plot. The first sample was taken after 70 days from planting (during tasseling-silking stage), as the entire leaf of the ear node from 5 plants/plot. Leaf plants were washed with diluted $\mathrm{HCl} 0.01 \mathrm{M}$ followed by rapid washing with distilled water, oven dried at $70^{\circ} \mathrm{C}$., ground and kept for chemical analysis. The second sample was taken at the harvest time from the grains of each plot to determine 100 grains weight (gm) and chemical analysis. For chemical analysis, the grain samples were ground and kept. For grain yield each plot was harvested to determine grain yield $\left(\mathrm{kg} \mathrm{fed} .^{-1}\right)$. Plant analysis, plant samples were oven dried at $70^{\circ} \mathrm{C}$ for 24 hours, ground in porcelain mortar and stored for analysis. A sample of $0.5 \mathrm{~g}$ of the dried plant material was digested with a mixture of concentrated $\mathrm{H}_{2} \mathrm{SO}_{4}$ and $\mathrm{H}_{2} \mathrm{O}_{2} 30 \%{ }^{77}$ The digest was diluted with distilled water to a volume of 50 ml. Aliquots from this digest was analyzed for $\mathrm{N}, \mathrm{P}$ and $\mathrm{K}$ according to the following methods: Total nitrogen was determined using Kjeldahl digestion method. ${ }^{81}$ Total phosphorus was determined colorimetrically in the acid digest according to Page. ${ }^{78}$ Total potassium was determined using the Flame Photometer according to Page. ${ }^{78}$

\subsection{Statistical Analysis}

Appropriate analysis of variance was performed using COSTATE Computer Software. The significant differences among the mean of various treatments were established by the Least Significant Differences method (LSD) according to Gomez. ${ }^{82}$ The displayed parameters values are the mean of the two seasons. The previous studies confirmed that there is a great need for scientific research in all fields every time. ${ }^{83-94}$

\section{References}

1. Tolba M. S., Sayed M., Kamal El-Dean A. M., Hassanien R., Abdel-Raheem Sh. A. A., and Ahmed M. (2021) Design, synthesis and antimicrobial screening of some new thienopyrimidines. Org. Commun., 14 (4) 334-345.

2. Abdel-Raheem Sh. A. A., Kamal El-Dean A. M., Hassanien R., El-Sayed M. E. A., and Abd-Ella A. A. (2020) Synthesis and biological activity of 2-((3-Cyano-4,6-distyrylpyridin-2-yl)thio)acetamide and its cyclized form. Alger. $j$. biosciences, 01 (02) 046-050.

3. Abdel-Raheem Sh. A. A., Kamal El-Dean A. M., Abdul-Malik M. A., Hassanien R., El-Sayed M. E. A., Abd-Ella A. A., Zawam S. A., and Tolba M. S. (2022) Synthesis of new distyrylpyridine analogues bearing amide substructure as effective insecticidal agents. Curr. Chem. Lett., 11 (1) 23-28.

4. Bakhite E. A., Abd-Ella A. A., El-Sayed M. E. A., and Abdel-Raheem Sh. A. A. (2017) Pyridine derivatives as insecticides. Part 2: Synthesis of some piperidinium and morpholiniumcyanopyridinethiolates and their Insecticidal Activity. J. Saud. Chem. Soc., 21 (1) 95-104.

5. Kamal El-Dean A. M., Abd-Ella A. A., Hassanien R., El-Sayed M. E. A., Zaki R. M., and Abdel-Raheem Sh. A. A. (2019) Chemical design and toxicity evaluation of new pyrimidothienotetrahydroisoquinolines as potential insecticidal agents. Toxicol. Rep., 6 (2019) 100-104.

6. Gad M. A., Aref S. A., Abdelhamid A. A., Elwassimy M. M., and Abdel-Raheem Sh. A. A. (2021) Biologically active organic compounds as insect growth regulators (IGRs): introduction, mode of action, and some synthetic methods. Curr. Chem. Lett., 10 (4) 393-412.

7. Kamal El-Dean A. M., Abd-Ella A. A., Hassanien R., El-Sayed M. E. A., and Abdel-Raheem Sh. A. A. (2019) Design, Synthesis, Characterization, and Insecticidal Bioefficacy Screening of Some New Pyridine Derivatives. ACS Omega, 4 (5) 8406-8412.

8. Abdel-Raheem Sh. A. A., Kamal El-Dean A. M., Zaki R. M., Hassanien R., El-Sayed M. E. A., Sayed M., and AbdElla A. A. (2021) Synthesis and toxicological studies on distyryl-substituted heterocyclic insecticides. Eur. Chem. Bull., 10 (4) 225-229.

9. Abdel-Raheem Sh. A. A., Kamal El-Dean A. M., Hassanien R., El-Sayed M. E. A., and Abd-Ella A. A. (2021) Synthesis and characterization of some distyryl-derivatives for agricultural uses. Eur. Chem. Bull., 10 (1) 35-38.

10. Tolba M. S., Sayed M., Abdel-Raheem Sh. A. A., Gaber T. A., Kamal El-Dean A. M., and Ahmed M. (2021) Synthesis and spectral characterization of some new thiazolopyrimidinederivatives. Curr. Chem. Lett., 10 (4) 471-478.

11. Al-Taifi E. A., Abdel-Raheem Sh. A. A., and Bakhite E. A. (2016) Some reactions of 3-cyano-4-( $p$-methoxyphenyl)5-oxo-5,6,7,8-tetrahydroquinoline-2 $(1 H)$-thione; Synthesis of new tetrahydroquinolines and tetrahydrothieno[2,3b] quinolines. Assiut University Journal of Chemistry (AUJC), 45 (1) 24-32.

12. Abdel-Raheem Sh. A. A., Kamal El-Dean A. M., Hassanien R., El-Sayed M. E. A., Sayed M., and Abd-Ella A. A. (2021) Synthesis and spectral characterization of selective pyridine compounds as bioactive agents. Curr. Chem. Lett., 10 (3) 255-260.

13. Abdel-Raheem Sh. A. A., Kamal El-Dean A. M., Abdul-Malik M. A., Abd-Ella A. A., Al-Taifi E. A., Hassanien R., El-Sayed M. E. A., Mohamed S. K., Zawam S. A., and Bakhite E. A. (2021) A concise review on some synthetic routes and applications of pyridine scaffold compounds. Curr. Chem. Lett., 10 (4) 337-362.

14. Tolba M. S., Kamal El-Dean A. M., Ahmed M., Hassanien R., Sayed M., Zaki R. M., Mohamed S. K., Zawam S. A., and Abdel-Raheem Sh. A. A. (2022) Synthesis, reactions, and applications of pyrimidine derivatives. Curr. Chem. Lett., 11 (1) 121-138. 
15. Abdelhafeez I. A., El-Tohamy S. A., Abdul-Malik M. A., Abdel-Raheem Sh. A. A., and El-Dars F. M. S. (2022) A review on green remediation techniques for hydrocarbons and heavy metals contaminated soil. Curr. Chem. Lett., 11 (1) $43-62$.

16. Tolba M. S., Abdul-Malik M. A., Kamal El-Dean A. M., Geies A. A., Radwan Sh. M., Zaki R. M., Sayed M., Mohamed S. K., and Abdel-Raheem Sh. A. A. (2022) An overview on synthesis and reactions of coumarin based compounds. Curr. Chem. Lett., 11 (1) 29-42.

17. Bakhite E. A., Abd-Ella A. A., El-Sayed M. E. A., and Abdel-Raheem Sh. A. A. (2014) Pyridine derivatives as insecticides. Part 1: Synthesis and toxicity of some pyridine derivatives against Cowpea Aphid, Aphis craccivora Koch (Homoptera: Aphididae). J. Agric. Food Chem., 62 (41) 9982-9986.

18. Abdelhamid A. A., Elsaghier A. M. M., Aref S. A., Gad M. A., Ahmed N. A., and Abdel-Raheem Sh. A. A. (2021) Preparation and biological activity evaluation of some benzoylthiourea and benzoylurea compounds. Curr. Chem. Lett., 10 (4) 371-376.

19. Haggag W. M. (2013) Corn Diseases and Management. J. Appl. Sci. Res., 9 (1) 39-43.

20. Naeem M. U. H. A. M. M. A. D., Iqbal J. A. V. A. I. D., and Bakhsh M. A. A. (2006) Comparative study of inorganic fertilizers and organic manures on yield and yield components of mungbean (Vigna radiat L.). J. Agric. Soc. Sci., 2 (4) 227-229.

21. Nyle C., and Brady R. (2003) Nature and properties of soil. $13^{\text {th }}$ ed., New York, 960 pp.

22. Goel A. K., Laura R. D., Pathak D. V., and Goel A. (1999) Use of biofertilizers: Potential, constraints and future strategies-a review. Inter. J. Trop. Agric., 17 (1/4) 1-18.

23. Saini V. K., Bhandari S. C., and Tarafdar J. C. (2004) Comparison of crop yield, soil microbial C, N and P, N-fixation, nodulation and mycorrhizal infection in inoculated and non-inoculated sorghum and chickpea crops. Field Crops Res., 89 (1) $39-47$.

24. Namvar A., Khandan T., and Shojaei M. (2012) Effects of bio and chemical nitrogen fertilizer on grain and oil yield of sunflower (Helianthus annuus L.) under different rates of plant density. Ann. Biol. Res., 3 (2) 1125-1131.

25. Rana A., Joshi M., Prasanna R., Shivay Y. S., and Nain L. (2012) Biofortification of wheat through inoculation of plant growth promoting rhizobacteria and cyanobacteria. Eur. J. Soil Biol., 50 118-126.

26. Abdelzaher M. A., Ibrahim Z. I., Khalil F.A., and Mohamed W.S. (2017) Use of some organic and Bio fertilizers as a partial substitution of the mineral nitrogen fertilization for corn, 1- The effect on corn yield and N, P and K uptake. Assiut J. Agric. Sci., 48 (1-1) 229-250.

27. Hauka F. I. A. (2000) Effect of using single and composite inoculation with Azospirillum brasilense, Bacillus megaterium var. phosphaticum and Glomus macrocarpus for improving growth of Zea mays. J. Agric. Sci. Mansoura Univ., 25 (4) 2327-2338.

28. El-Sawah M. M. A. (2000) Impact of composed inoculation with $\mathrm{N}_{2}$-fixing, phosphate-solubilizing bacteria and Vesicular-Arbuscular Mycorrhiza on growth and nutrition of maize plants in a calcareous soil. J. Agric. Sci. Mansoura Univ., 25 (4) 2339-2350.

29. Anonymous A. M. (2010) Humic and fulvic acids: The black gold of agriculture. Retrieved from www.humintech.com/ pdf/ humic fulvic acids.pdf.

30. Mauromicale G., Longo A. M. G., and Monaco A. L. (2011) The effect of organic supplementation of solarized soil on the quality of tomato fruit. Sci. Hortic., 129 (2) 189-196.

31. Moghadam H. R. T., Khamene M. K., and Zahedi H. (2014) Effect of humic acid foliar application on growth and quantity of corn in irrigation withholding at different growth stages. Maydica, 59 (2) 124-128.

32. El-Mekser H. K. A., Zeinab E. G., and Hoda E. A. I. (2015) Nitrogen fertilizer and humic acid effects on maize productivity. Egypt J. Agric. Res., 2 93-96.

33. Roozbahani A. (2015) Effect of soil application of humic acid and fulvic acid on agronomic traits of barley. J. Crop Nutr. Sci., 1 (2) 12-17.

34. Derby N. E., Casey F. X., Knighton R. E., and Steele D. D. (2004) Midseason nitrogen fertility management for corn based on weather and yield prediction. Agron. J., 96 (2) 494-501.

35. Zeidan M. S., Amany A., and El-Kramany M. F. (2006) Effect of N-fertilizer and plant density on yield and quality of maize in sandy soil. Res. J. Agric. Biol. Sci., 2 (4) 156-161.

36. Munda G. C., Islam M., and Patel D. P. (2007) Effect of IPNS on productivity, profitability and economic feasibility of maize based cropping system on farmers' field. Indian J. Agric. Res., 41 (3) 200-204.

37. Islam M., and Munda G. C. (2012) Effect of organic and inorganic fertilizer on growth, productivity, nutrient uptake and economics of maize (Zea mays L.) and toria (Brassica campestris L.). Agric. Sci. Res. J., 2 (8) 470-479.

38. Kader M. A., Mian M. H., and Hoque M. S. (2002) Effects of Azotobacter inoculant on the yield and nitrogen uptake by wheat. J. Biol. Sci., 2 (4) 259-261.

39. Baral B. R., and Adhikari P. (2013) Effect of Azotobacter on growth and yield of maize. SAARC J. Agric., 11 (2) 141147.

40. Beyranvand H., Farnia A., Nakhjavan S. H., and Shaban M. (2013) Response of yield and yield components of maize (Zea mayz L.) to different bio fertilizers. Int. J. Adv. Biol. Biomed. Res., 1 (9) 1068-1077.

41. Hellal F. A., Zewainy R. M., Khalil A. A., and Ragab A. A. M. (2014) Effect of organic and bio-fertilizer management practices on nutrient availability and uptake by Faba bean-Maize sequence. Am. Eurasian. J. Agric. Environ. Sci., 8 (5) 35-43. 
42. Puglisi E., Fragoulis G., Ricciuti P., Cappa F., Spaccini R., Piccolo A., ... and Crecchio C. (2009) Effects of a humic acid and its size-fractions on the bacterial community of soil rhizosphere under maize (Zea mays L.). Chemosphere, 77 (6) 829-837.

43. Celik H., Katkat A. V., Asik B. B., and Turan M. A. (2010) Effects of humus on growth and nutrient uptake of maize under saline and calcareous soil conditions. Žemdirbyste (Agriculture), 97 (4) 15-22.

44. Sharif M., Khattak R. A., and Sarir M. S. (2002) Effect of different levels of lignitic coal derived humic acid on growth of maize plants. Commun. Soil Sci. Plant Anal., 33 (19-20) 3567-3580.

45. Azeem K., Khalil S. K., Khan F., Qahar A., Sharif M., and Zamin M. (2014) Phenology, yield and yield components of maize as affected by humic acid and nitrogen. J. Agric. Sci., 6 (7) 286-293.

46. Kuşvuran V. S. A., and Babat S. (2011) The effect of different humic acid fertilization on yield and yield components performances of common millet (Panicum miliaceum L.). Sci. Res. Essays, 6 (3) 663-669.

47. Bakry B. A., Elewa T. A., El-Kramany M. F., and Wali A. M. (2013) Effect of humic and ascorbic acids foliar application on yield and yield components of two wheat cultivars grown under newly reclaimed sandy soil. Int. J. Agron. Plant Prod., 4 (6) 1125-1133.

48. Wu S. C., Cao Z. H., Li Z. G., Cheung K. C., and Wong M. H. (2005) Effects of biofertilizer containing N-fixer, P and K solubilizers and AM fungi on maize growth: a greenhouse trial. Geoderma, 125 (1-2) 155-166.

49. Abou El-Magd M. A., El-Bassiony M., and Fawzy Z. F. (2006) Effect of organic manure with or without chemical fertilizers on growth, yield and quality of some varieties of Broccoli plants. World Appl. Sci. J., 2 (10) 791-798.

50. Waqas M., Ahmad B., Arif M., Munsif F., Khan A. L., Amin M., Kang S. M., Kim Y. H., and Lee I. J. (2014) Evaluation of humic acid application methods for yield and yield components of mungbean. Am. J. Plant Sci., 5 2269-2276.

51. Vanitha K., and Mohandass S. (2014) Effect of humic acid on plant growth characters and grain yield of drip fertigated aerobic rice (Oryza sativa L.). The bioscan, 9 (1) 45-50.

52. Khang V. T. (2011) Fulvic foliar fertilizer impact on growth of rice and radish at first stage. Omonrice, 18 144-148.

53. Poapst P. A., and Schnitzer M. (1971) Fulvic acid and adventitious root formation. Soil Biol. Biochem., 3 (3) $215-219$.

54. Ahmad W., Shah Z., Khan F., Ali S., and Malik W. (2013) Maize yield and soil properties as influenced by integrated use of organic, inorganic and bio-fertilizers in a low fertility soil. Soil Environ., 32 (2) 121-129.

55. Farnia A., and Torkaman H. (2015) Effect of different biofertilizers on yield and yield components of maize (Zea mays L.). Bull. Environ. Pharmacol. Life Sci., 4 (4) 75-79.

56. Fathi A., Oshterinani F., Mahmoodi M., and Barari T. D. (2015) Biological effects of nitrogen and phosphate fertilizers on yield and yield components of corn AS71. Adv. agric. biol., 4 (4) 127-131.

57. Meena M. D., Tiwari D. D., Chaudhari S. K., Biswas D. R., Narjary B., Meena A. L., ... and Meena R. B. (2013) Effect of biofertilizer and nutrient levels on yield and nutrient uptake by maize (Zea mays L.). Ann. Agri. Bio. Res., 18 (2) 176-181.

58. Dutta D., Kumar V., and Singh S. (2014) Effect of nitrogen, farm yard manure, Azotobacter interaction on rhizospheric population of Azotobacter and yield of maize in mollisol of Uttarakhand. Bioscience, 1 (2) 11-15.

59. El-Yazied A., Ragab M. E., Ibrahim R. E., and El-Wafa A. (2007) Effect of nitrogen fertigation levels and chelated calcium foliar application on the productivity of sweet corn. Arab Univ. J. Agric. Sci., 15 (1) 131-139.

60. Hussaini M. A., Ogunlela V. B., Ramalan A. A., and Falaki A. M. (2008) Mineral composition of dry season maize (Zea mays L.) in response to varying levels of nitrogen, phosphorus and irrigation at Kadawa, Nigeria. World J. Agric. Res., 4 (6) 775-780.

61. Nsanzabaganwa E., Das T. K., Rana D. S., and Kumar S. N. (2014) Nitrogen and phosphorus effects on winter maize in an irrigated agroecosystem in western Indo-Gangetic plains of India. Maydica, 59 (2) 152-160.

62. Shivay Y. S., Singh R. P., and Shivakumar B. G. (2002) Effect of nitrogen on yield attributes, yield and quality of maize (Zea mays) in different cropping systems. Indian J. Agric. Sci., 72 (3) 161-163.

63. Kar P. P., Barik K. C., Mahapatra P. K., Garnayak L. M., Rath B. S., Bastia D. K., and Khanda C. M. (2006) Effect of planting geometry and nitrogen on yield, economics and nitrogen uptake of sweet corn (Zea mays). Indian J. Agron., 51 (1) $43-45$.

64. Singh G., Sharma G. L., Golada S. L., and Choudhary R. (2012) Effect of integrated nutrient management on quality protein maize (Zea mays L.). Crop Res., 44 26-29.

65. Dadarwal R. S., Jain N. K., and Singh D. (2009) Integrated nutrient management in baby corn (Zea mays). Indian J. agric. Sci., 79 (12) 1023-1025.

66. Balai M. L., Verma A., Nepalia V., and Kanthaliye P. C. (2011) Productivity and quality of maize (Zea mays) as influenced by integrated nutrient management under continuous cropping and fertilization. Indian J. agric. Sci., 81 (4) 374-376.

67. Daur I., and Bakhashwin A. A. (2013) Effect of humic acid on growth and quality of maize fodder production. Pak. $J$. Bot., 45 (S1) 21-25.

68. Akhtar K., Shah S. N. M., Ali A., Zaheer S., Wahid F., Khan A., Shah M., Bibi S., and Majid A. (2014) Effects of humic acid and crop residues on soil and wheat nitrogen contents. Am. J. Plant Sci., 5 (9) 1277-1284.

69. Delfine S., Tognetti R., Desiderio E., and Alvino A. (2005) Effect of foliar application of N and humic acids on growth and yield of durum wheat. Agron. Sustain. Dev., 25 (2) 183-191.

70. Morard P., Eyheraguibel B., Morard M., and Silvestre J. (2010) Direct effects of humic-like substance on growth, water, and mineral nutrition of various species. J. plant nutr., 34 (1) 46-59. 
71. Chen Z. D., He J. M., Li X. Y., and Chen J. M. (2007) Studies on increasing N utilizing efficiency in maize by applying humic acid. Chin. J. Eco-Agric., 15 (1) 52-54.

72. Mackowiak C. L., Grossl P. R., and Bugbee B. G. (2001) Beneficial effects of humic acid on micronutrient availability to wheat. Soil Sci. Soc. Am. J., 65 (6) 1744-1750.

73. Bais H. P., Weir T. L., Perry L., Gilroy S., and Vivanco J. M. (2006) The role of root exudates in rhizosphere interactions with plants and other organisms. Annu. Rev. Plant Biol., 57 233-266.

74. Diaz-Zorita M., and Fernandez-Canigia M. V. (2009) Field performance of a liquid formulation of Azospirillum brasilense on dryland wheat productivity. Eur. J. soil. biol., 45 (1) 3-11.

75. Ghaderi-Daneshmand N., Bakhshandeh A., and Rostami M. R. (2012) Biofertilizer affects yield and yield components of wheat. Int. J. Agric. Sci., 2 (6) 699-704.

76. Dewis J., and Freitas F. (1970) Physical and chemical methods of soil and water analysis. FAO Soils Bulletin, 101 275.

77. Jackson M. L. (1973) Soil Chemical Analysis, prentice hall of India Pvt. Ltd., New Delhi, India, 498 151-154.

78. Page A. L., Miller R. H., and keeney D. R. (1982) Methods of Soil Analysis. Part 2: Chemical and Microbiological Properties. Amer. Soc. Agron. Soil Sci. Soc. Amer. In, Madison, Wisconsin, USA.

79. Olsen S. R. (1954) Estimation of available phosphorus in soils by extraction with sodium bicarbonate (No. 939). US Department Of Agriculture, Washington.

80. Navarro A. F., Cegarra J., Roig A., and Garcia D. (1993) Relationships between organic matter and carbon contents of organic wastes. Bioresour. Technol., 44 (3) 203-207.

81. Black C. A., Evans D. D., Ensminger L. E., White J. L., Clark F. E., and Dinauer R. C. (1965) Methods of Soil Analysis. Part 2: Chemical and Microbiological Properties. Amer. Soc. Agron. Soil Sci. Soc. Amer. In, Madison, Wisconsin, USA.

82. Gomez K. A., and Gomez A. A. (1984) Statistical procedures for Agriculture Research. ${ }^{\text {nd }}$ Ed. John Willey and Sons Inc. New York.

83. Ahmed M., Younis O., Orabi E. A., Sayed A. M., Kamal El-Dean A. M., Hassanien R., Davis R. L., Tsutsumi O., and Tolba M. S. (2020) Synthesis of novel thienopyrimidines as biocompatible chromophores with aggregation-induced emission sensitive to molecular aggregation. ACS Omega, 5 (46) 29988-30000.

84. Tolba M. S., Kamal El-Dean A. M., Ahmed M., Hassanien R., and Farouk M. (2017) Synthesis and Antimicrobial Activity of Some New Thienopyrimidine Derivatives. Arkivoc, 2017 (5) 229-243.

85. Tolba M. S., Ahmed M., Kamal El-Dean A. M., Hassanien R., and Farouk M. (2018) Synthesis of new fused thienopyrimidines derivatives as anti-inflammatory agents. J. Heterocyclic Chem., 55 (2) 408-418.

86. Younis O., Tolba M. S., Orabi E. A., Kamal A. M., Hassanien R., Tsutsumi O., and Ahmed M. (2020) Biologicallyactive heterocyclic molecules with aggregation-induced blue-shifted emission and efficient luminescence both in solution and solid states. J. Photochem. Photobiol. A., 400 (2020) 112642-112653.

87. Tolba M. S., Kamal El-Dean A. M., Ahmed M., and Hassanien R. (2019) Synthesis, reactions, and biological study of some new thienopyrimidine derivatives as antimicrobial and antiInflammatory agents. J. Chin. Chem. Soc., 66 (5) 548557.

88. Hamed M. M., Kamal El-Dean A. M., Abdel-Mohsen Sh. A., and Tolba M. S. (2021) New Diclofenac Derivatives as Anti-Microbial, Anti-Inflammatory Agents: Design, Synthesis, Biological Screening, and Molecular Docking Study. Russ. J. Bioorganic Chem., 47 (1) 208-220.

89. Tolba M. S., Sayed A. M., Sayed M., and Ahmed M. (2021) Design, synthesis, biological evaluation, and molecular docking of some new Thieno [2,3-d] pyrimidine derivatives. J. Mol. Struct., 1246131179.

90. Mohamed A. M. G., Mohamed M. M. A., Farrag A. E. H. A., and Ali A. S. R. M. (2021) Novel elimination method of iron and manganese ions from drinkable groundwater in Assiut, Egypt, by using sodalite-bearing modified illite. Environ. Sci. Pollut. Res., Accepted Manuscript (DOI: 10.1007/s11356-021-17765-z).

91. Mubarak M. F., Mohamed A. M. G., Keshawy M., Abd elMoghny T., and Shehata N. (2021) Adsorption of heavy metals and hardness ions from groundwater onto modified zeolite: Batch and column studies. Alex. Eng. J., Accepted Manuscript (DOI: 10.1016/j.aej.2021.09.041).

92. Mahmoud E. A., Mohamed A. M. G., and Aboeldahb S. A. (2021) Evaluation of the most promising techniques overcoming the algal problems takes place during the purification of drinking water. Environ. Sci. Pollut. Res., 28 44239-44248.

93. Fathy M., Zayed M. A., and Mohamed A. M. G. (2019) Phosphate adsorption from aqueous solutions using novel Zn Fe/Si MCM-41 magnetic nanocomposite: characterization and adsorption studies. Nanotechnol. Environ. Eng., 4 (1) $1-12$.

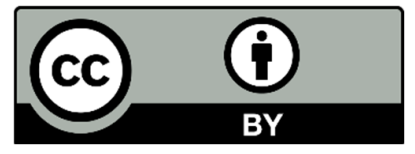

(C) 2022 by the authors; licensee Growing Science, Canada. This is an open access article distributed under the terms and conditions of the Creative Commons Attribution (CC-BY) license (http://creativecommons.org/licenses/by/4.0/). 